\title{
ARTICLES
}

\section{Joint Criminal Enterprise before the Chambres Africaines Extraordinaires}

\author{
Hissène Habré's Direct and Indirect Criminal Liability
}

Kerstin Bree Carlson*

\begin{abstract}
The Chambres Africaines Extraordinaires (CAE), ad hoc chambers operating under the auspices of the Dakar municipal courts, were constructed to try Hissène Habré. In targeting Habré, the CAE was designed to appease Chadian calls for justice (from Habrés victims, on one hand, and the Déby regime, on the other), resolve Senegal's impasse over the legality of Habrés culpability and allow the African Union to meet its leadership obligations. To this tall order, the CAE was required to exercise legitimate judicial authority in the contested sphere of international criminal law (ICL), where content is pluralist and political.

This article examines the CAE's finding of Habrés culpability for war crimes, crimes against humanity and torture. The article shows that the CAE applied a novel construction of liability under ICL and argues that it did so in order to strengthen its authority and legitimacy. By so doing, the CAE has made a significant addition to the field of ICL. This article explores the CAE's application of joint criminal enterprise (JCE) to consider how the internationally formulated doctrinal standard is reshaped by CAE practice.
\end{abstract}

Keywords: International criminal law, Joint criminal enterprise, Complicity, Chambres Africaines Extraordinaires / Extraordinary African Chambers, Hybrid tribunals.

The Chambres Africaines Extraordinaires (CAE), ad hoc chambers operating under the auspices of the Dakar municipal courts, were constructed to try Hissène Habré. Habré led Chad from 1982 until 1990, when he was deposed by his former second in command, Idriss Déby. Déby remains the head of state of Chad today and has long agitated to recognize Habré's (and only Habré's) misdeeds and punish him. In targeting Habré, the CAE was designed to appease Chadian calls for justice (from Habrés victims, on one hand, and the Déby regime, on the other), resolve Senegal's impasse over the legality of Habré's culpability and allow the African Union to meet its leadership obligations. To this tall order, the CAE

* University of Southern Denmark and The American University of Paris. 
was required to exercise legitimate judicial authority in the contested sphere of international criminal law (ICL), where content is pluralist and political. Thus the CAE, an institution created by compromise between Chad, Senegal, the African Union and interested donor states, came into existence itself compromised, because creating an institution to try an individual is a backward application of the rule of law and challenges central notions of justice.

In the past 30 years, ICL-practicing institutions have developed an extensive, though uneven, jurisprudence regarding complicity (the liability levied against those who do not perpetrate crimes themselves). Habré ran a repressive state that killed and injured tens of thousands of Chadians, and his crimes were understood as those accomplished by the leader of an illiberal state. In its 2016 judgment, however, the CAE found Habré indirectly as well as directly culpable for each of categories of crime charged. This included a controversial finding that Habré, personally, had raped Khadija Hassan Zidane (this finding was overturned on appeal for procedural reasons). This article examines the CAE's finding of Habrés culpability for war crimes, crimes against humanity and torture. The article shows that the CAE applied a novel construction of liability under ICL and argues that it did so in order to strengthen its authority and legitimacy. By so doing, the CAE has made a significant addition to the field of ICL. This article explores the CAE's application of joint criminal enterprise (JCE) to consider how the internationally formulated doctrinal standard is reshaped by CAE practice.

\section{Complicity at ICL}

International criminal law is a body of jurisprudence that finds individuals liable for violations of core rights recognized under international humanitarian law (IHL). IHL governs the conduct of armed conflict and has been developing in modern form for two centuries. ICL was born at Nuremberg and Tokyo following World War II. ICL was built on recognized universals emerging from IHL (like war crimes) and added important novel categories (crimes against humanity; aggression; and later genocide) following the specific experiences of the war. ICL diverged importantly from IHL in several respects, the most significant of which were these new legal categories as well as the potential to apply them to individual perpetrators who might then be punished, including (in its original form, at Nuremberg and Tokyo) by death.

The Nuremberg Tribunal (and, less famously, its sister tribunal at Tokyo) faced several challenges in laying the jurisprudential foundations of ICL. The categories it articulated were new to law, and in forming a legal response to statesponsored violence, ICL violated central legal tenets proscribing the retroactive application of law (May 2014). Moreover, the atrocities it sought to address (especially those perpetrated by the Nazi forces, and perhaps only to a lesser extent the Japanese) were not acts of lawlessness but were rather rooted in a terrible, totalitarian lawfulness. Thus the charge both tribunals faced - that they were purveyors of victor's 'justice' and therefore no justice at all - rang all the more bitterly, coming as they did on the heels of the horrific legal measures that 
had led to the organized slaughter of millions of men, women and children. ICL met these challenges by rooting itself in what Günther Teubner has termed 'sociological natural law'. Teubner calls this construction of natural law sociological because it "uses societal constitutions to reconstruct the rationalities of diverse subsystems within the legal system and transform them into binding principles" (Teubner 2015: 10). ICL's mandate of progressiveness was designed to overcome the legality challenge encompassed in the retroactivity prohibition nullum crimen sine lege. Where most law gains legitimacy by establishing historical rootedness, ICL asserts legitimacy by proclaiming it represents 'progress' (Carlson 2017). A modern example of this legitimizing function is on display at the International Criminal Court (ICC; established in 2002), where the entryway to the court is inscribed with the phrase 'towards a more just world'.

Beyond political challenges, ICL faced doctrinal challenges in the content of its legal construction. How, for example, do you define individual intent when prosecuting crimes that are necessarily linked to state formation and collective identity (Drumbl 2007; Fletcher 2004)? In the destructive theatre of war, how do you prove criminal commission with evidence often far shabbier than what is established as necessary for a fair trial? The architects of the Nuremberg Tribunal imagined that a form of collective responsibility, membership in an illegal organization, could provide a shorthand for the problems of intent and commission. This would have made it possible to impute intent and liability for crimes committed in service to an organization across a group of individuals connected to that organization. Yet the Nuremberg judges rejected this suggestion, and the prohibition against guilt by association remains, formally at least, rejected at ICL today. ${ }^{1}$

The resurgence of ICL with the ad hoc tribunals for Yugoslavia (International Criminal Tribunal for the former Yugoslavia [ICTY]) and Rwanda (ICTR), and the permanent ICC, reanimated the work-a-day problem of commission, that is, how one 'does crime'. For most atrocity crimes, direct commission remains the purview of low-level perpetrators. ICL, as part of its progress narrative, generally reserves the right to sit in judgment against any violator of IHL. This is spurred, arguably in equal part, by the normative recognition of Arendt's (2006 [1963]) "banality of evil" analytical formulation, that horrible atrocities are made possible only by one thousand small acts which in themselves, or in another context, might not be criminal, and that these must be deterred, as well as by the institutional recognition that to establish the facts of state crime, the easiest method for building a case is from the ground up. Yet the central truths ICL seeks to assert regarding challenging impunity for atrocity crimes have greatest resonance when addressed to power, and it is the orchestrators, leaders, designers and catalysts of atrocity crimes that form the true target of ICL efforts, as well as the true measures of its success. Given the very high cost of trying any individual before inter-

1 Report of the Secretary General pursuant to para. 2 of Security Council Resolution 808 (1993), 3 May 1993 (S/25704), §§ 50, 51. This was reaffirmed in Prosecutor v. Milomir Stakić, Case No. IT-97-24 (22 March 2006). 
national criminal institutions, there are also practical considerations that speak in favour of targeting leaders.

To address actors with moral and intellectual blood on their hands, ICL defines several indirect modes of commission, considered collectively as 'complicity' (Jain 2014; Aksenova 2016). For those higher up the hierarchy, complicity is generally the mode by which individual criminal liability is established. An individual need not personally have committed crimes to be found complicit in their commission and thus to be guilty of those crimes under ICL. ICL has developed at least two $^{2}$ parallel, separate, strands of complicity jurisprudence, which emerge out of the ad hoc courts of the ICTY and ICTR, on the one hand, and the ICC on the other. This article briefly describes the distinctions and overlaps of these two approaches. Greater focus is granted to JCE, the approach developed by the ICTY/ ICTR, as this is the approach followed by the CAE.

\subsection{Joint Criminal Enterprise}

'Joint Criminal Enterprise' is nowhere located in the ICTY or ICTR statutes, nor was it, before its development at the ICTY, any meaningful criterion of ICL practice. JCE is a theory of liability based in the ICTY's 'commission' jurisdiction; it is, in other words, a theory of how the ICTY recognizes defendants 'do' (commit) a crime. The first element of Article 7 (Individual Criminal Responsibility) of the ICTY statute reads: " 1 . A person who planned, instigated, ordered, committed or otherwise aided and abetted in the planning, preparation or execution of a crime referred to in articles 2 to 5 of the present Statute, shall be individually responsible for the crime." ${ }^{3}$ It is from this aspect of 'commission' that JCE emerged.

As developed by the ICTY, there are three arms of JCE. JCE I concerns coperpetration, cases where all actors, in pursuit of a common plan, possess the same criminal intention. ${ }^{4}$ JCE II, termed a variant of JCE I, applies this common plan to concentration camp cases. In the most far-reaching and controversial arm of the doctrine, JCE III, guilt rides on the foreseeability that crime will result from conduct. Under the JCE III doctrine, the Appeals Chamber found the defendant guilty of a murder in a location it could not show he had physically been. ${ }^{5} \mathrm{JCE}$ has been heavily criticized by a wide range of commentators and nearly universally critiqued outside the doctrinal halls of ICL practice.

From its articulation in the 1999 Tadić appeals judgment, ${ }^{6}$ JCE went on to become the ICTY's workhorse, featuring in nearly all ICTY convictions. JCE applies legal reasoning developed in World War II-era case law to interpret Article 7.1 of the ICTY Statute concerning individual criminal responsibility. At the ICTY,

2 Some would argue that the ad hoc tribunals' distinct 'perpetration' and 'aiding and abetting' jurisprudence constitute distinct forms of commission in themselves; this line of argument exceeds the limitations of this article.

3 ICTY Statute.

4 Judgment, The Prosecutor v. Duško Tadić, Case No. IT-94-1-T, Appeals Chamber (15 July 1999), para. 196.

5 Judgment, The Prosecutor v. Duško Tadić, Case No. IT-94-1-T, Appeals Chamber (15 July 1999).

6 The Prosecutor v. Duško Tadić, Case No. IT-94-1-T, Appeals Chamber (15 July 1999). 
JCE is sometimes privately referred to as 'just convict everybody'. ${ }^{7} \mathrm{JCE}$ mitigates the evidentiary challenges arising at ICL by making it possible to prosecute anyone found to share 'the same criminal intent' ${ }^{8}$ with whomever perpetrated a crime, even where such perpetrator is unknown. This addresses difficulties in chain of command structures otherwise necessary in proving command responsibility (Danner \& Martinez 2005; Van Sliedregt 2011), as well as offering the possibility of tying various individuals to any given crime.

The 'intent' elements of JCE were articulated in a case following closely on the heels of the final Tadić judgment and arising from the same Omarska prison camp where Tadić participated in violent crimes: Kvočka et al. ${ }^{9}$ The case involved a number of 'guards' at the Omarska prison camp. The named defendant, Miroslav Kvočka, was a police officer. He served at the camp for a total of 17 days, committed no crimes and intervened on a number of occasions to stop violence, including once stepping between a shooter and a group of prisoners. The Trial Chamber, however, determined that Kvočka's awareness of the terrible conditions in the camp (beatings, deaths, lack of food) constituted the legal equivalent of intent. Finding that Kvočka did not commit any of the crimes committed at Omarska, the Trial Chamber found him liable as a co-perpetrator because he:

could have done far more to mitigate the terrible conditions in the camp... [by] tak[ing] steps within his designated authority to more actively prevent unauthorized outsiders from entering the camp and abusing detainees... ensur[ing] more detainees received medical treatment... prevent[ing] guards and other subordinates from beating or otherwise abusing detainees on arrival, in the dining room, or en route to the toilets. ${ }^{10}$

As regards Kvočka's co-defendants, the Trial Chamber ultimately found a spectrum of commission, from defendants who actively participated in violence to those who watched detainee abuse passively, to those who pretended that things were normal when evidence clearly showed otherwise, concluding, "All three attitudes deserve to be punished."11

\subsection{The End of JCE?}

JCE has been critiqued for its possibility to 'weaken' ICL (Danner \& Martinez 2005) or imperil ICL's coherence (Osiel 2005). Nonetheless, JCE enjoyed great institutional success; following its first iteration in the Tadić appeals judgment (15 July 1999), JCE functioned as a standard-bearing theory of liability, forming the

7 Author interviews, The Hague, May 2005. See also Ohlin (2009); Badar (2006).

8 Judgment, The Prosecutor v. Duško Tadić, Case No. IT-94-1-T, Appeals Chamber (15 July 1999), para. 220.

9 Judgment, Prosecutor vs. Miroslav Kvočka, Mlađo Radić, Zoran Žigić, Dragoljub Prcać, IT-98-30/1-T (Int'l Crim. Trib. for the Former Yugoslavia 2 November 2001).

10 Kvočka Trial Chamber, para. 395.

11 Ibid., para. 709. 
basis of the majority of the ICTY's post-Tadic indictments, for example. ${ }^{12}$ As the ICTY began to look towards the end of its mandate and prepare its 'legacy', however, it began 'walking back' its JCE jurisprudence (Carlson 2018).

The retreat of JCE as the ICTY's powerhouse theory of liability was signalled by the Gotovina appeals judgment in November 2012. There the Appeals Chamber reversed the Trial Chambers' 27-year sentence against Croatian General Ante Gotovina, acquitting him and his co-defendant, Commander of Croatian Special Police Mladen Markač. ${ }^{13}$ This was followed by acquittals for Serbian military and political leaders: Perišić (2013), ${ }^{14}$ Stanišić and Simatović $\left(2013^{15}\right.$ retrial ordered $2015^{16}$ ) and, in March 2016, Šešelj. ${ }^{17}$ In the case of Prosecutor v. Jovica Stanišić \& Franko Simatović, ${ }^{18}$ the ICTY acquitted two senior Serb leaders indicted under JCE charges in the Trial Chamber considering the actions of those two Serb generals, whom it found directed, supplied and organized troops who were active in violence in Croatia and throughout Bosnia, through an "inference of intent ... to share common criminal purpose" paradigm. The Trial Chamber, in a 2-1 decision, found evidence insufficient to support this mens rea standard, which is much more lenient than the 'knowledge' standard applied in Kvočka et al (2001).

\subsection{Commission before the ICC}

Although the ICC has formally declined to recognize JCE jurisprudence, it employs a similar theory of liability that makes it possible to capture "partici-

12 Marston \& Danner (2005: 108) estimate that 64\% of indictments between 2001 and 2004 (when indictments ceased) relied on JCE and "[i]f all indictments that include charges that the defendant acted 'in concert' with others are viewed as implicitly employing a JCE theory, then thirtyfour of the forty-three indictments confirmed between 25 June 2001 and 1 January 2004 (81\% of the total), incorporate JCE."

13 Prosecutor vs. Ante Gotovina, Ivan Čermak and Mladen Markač, Case No. IT-06-90-PT (Int'l Crim. Trib. for the Former Yugoslavia 16 November 2012).

14 Prosecutor v. Momčilo Perišić, Case No. IT-04-81 (Int'l Crim. Trib. for the Former Yugoslavia 28 February 2013).

15 Prosecutor v. Jovica Stanišić \& Franko Simatović, Case No. IT-03-69 (Int'l Crim. Trib. for the Former Yugoslavia 30 May 2013). In 2015, an ICTY Appeals Chamber ruled the case should be retried over the evidentiary standard necessary to establish a JCE.

16 Prosecutor v. Jovica Stanišić \& Franko Simatović, Case No. IT-03-69 (Int'l Crim. Trib. for the Former Yugoslavia 15 December 2015). As regards the joint criminal enterprise portion of the 2013 judgment, the Appeals Chamber determined that "the absence of a thorough analysis and prior findings on the existence and scope of a common criminal purpose shared by a plurality of persons as well as on Stanišić's and Simatović's contribution to it", meant that "the Trial Chamber could not have properly adjudicated Stanišićs and Simatović's mens rea". The first Stanišić and Simatović trial lasted several years, and involved nearly 5000 exhibits and more than 100 witnesses. The Appeals Chamber Judgment sending the case to retrial means, effectively, that we are again years away from seeing how an international tribunal applies juridical constructions of 'intent' to facts it establishes.

17 Prosecutor v. Vojislav Šešelj, Case No. IT-03-67 (Int'l Crim. Trib. for the Former Yugoslavia March 2016; the Appeals Chamber partially overturned the acquittal, sentencing Šešelj to 10 years, that is, time served. Prosecutor v. Vojislav Šešelj, Case No. IT-03-67 (Int'l Crim. Trib. for the Former Yugoslavia 11 April 2018).

18 Prosecutor v. Jovica Stanišić \& Franko Simatović, Case No. IT-03-69 (Int'l Crim. Trib. for the Former Yugoslavia 30 May 2013). 
pants" removed from immediate violence (Ohlin 2009). Article 25 of the Rome Statute governs individual criminal responsibility. Regarding commission, Article 25(3) reads, in its entirety:

3. In accordance with this Statute, a person shall be criminally responsible and liable for punishment for a crime within the jurisdiction of the Court if that person:

a Commits such a crime, whether as an individual, jointly with another or through another person, regardless of whether that other person is criminally responsible;

b Orders, solicits or induces the commission of such a crime which in fact occurs or is attempted;

c For the purpose of facilitating the commission of such a crime, aids, abets or otherwise assists in its commission or its attempted commission, including providing the means for its commission; ${ }^{19}$

Ohlin (2009) argues that 25(3)(a) is functionally equivalent to JCE I. This is contested by, among others, Kevin Jon Heller, who argues that 25(3)(c) concerns contributions made to group crime "made by individuals who are not members of the group." 20

William Schabas (2012) has argued that, having learned from the ad hocs that preceded it, the ICC took great care to constrain judicial interpretation through a more precisely articulated statute. Regardless, the ICC Pre-Trial Chamber in the Lubanga case ${ }^{21}$ applied a theory developed by Claus Roxin after World War II to ascribe liability to Nazi actors, the "control theory", 22 to Article 25's co-perpetration and indirect perpetration. The Pre-Trial defined "control" as "joint control over the crime by reason of the essential nature of the various contributions to the commission of the crime" 23 and further iterated:

when the objective elements of an offence are carried out by a plurality of persons acting within the framework of a common plan, only those to whom essential tasks have been assigned - and who, consequently, have the power to frustrate the commission of the crime by not performing their tasks - can be said to have joint control over the crime. ${ }^{24}$

19 Rome Statute of the International Criminal Court, Art. 25(3)(a)-(c).

20 See http://opiniojuris.org/2012/03/16/lubanga-decision-roundtable-more-on-co-perpetration/ (last accessed 25 October 2018). For diverging opinions on the question of pluralism / fragmentation in ICL, see Koskenniemi (2007) and Greenawalt (2012).

21 Prosecutor v. Thomas Lubanga Dyilo, Decision on the Confirmation of Charges, Pre-Trial Chamber, ICC01/04-01/06, 29 January 2007.

22 C. Roxin, 'Straftaten im Rahmen organisatorischer Machtsapparate', Goltdammer's Archiv für Strafrecht (GA), 1963, translated to English: C. Roxin, 'Crimes as Part of Organized Power Structures', JICJ, Vol. 9, 2011, pp. 193-205. Some ICC judges have rejected the "control theory" as inconsistent with the language of the ICC statute.

23 Prosecutor v. Thomas Lubanga Dyilo, Decision on the Confirmation of Charges, Pre-Trial Chamber, ICC01/04-01/06, 29 January 2007, para. 341.

24 Ibid., para. 347. 
This interpretation is challenged by some ICC judges ${ }^{25}$ and, seemingly, by the language of the Rome Statute itself (Ohlin, van Sliedregt \& Weigend 2013).

\section{Assessing Habré's Direct and Indirect Perpetration}

The Statute of the CAE mirrors other contemporary ICL tribunals and provides for culpability beyond direct commission. The Statute of the CAE defines the modes of individual criminal responsibility under its Article 10, "Individual Criminal Responsibility and Irrelevance of Official Capacity”. Article 10.2 reads:

A person who committed, ordered, planned or instigated others to commit, or otherwise aided and abetted in the planning, preparation or execution of a crime referred to in articles 5 to 8 of this Statute, shall be individually responsible for the crime, as a principal or accomplice. ${ }^{26}$

Article 10.4, charting command responsibility, reads:

The fact that any of the acts referred to in articles 5 to 8 of this Statute responsibility if the accused knew or had reason to know that the subordinate was about to commit such acts or had done so and the superior failed to take the necessary and reasonable measures to prevent such acts or to punish the perpetrators thereof. ${ }^{27}$

The investigating judges applied JCE and command responsibility as modes of commission in the Ordonnance. ${ }^{28}$ These modes of liability are well established in ICL. In practice, however, command responsibility has given way to prosecutorial use of the theory of liability of 'joint criminal enterprise', as the latter has generally been much easier to demonstrate (Danner \& Martinez 2005). The Ordonnance applied both command responsibility and JCE as standard, without discussing the controversies surrounding the doctrine. The investigating judges found that

See Separate Opinion of Judge Adrian Fulford to Prosecutor v. Thomas Lubanga Dyilo, Judgment, Trial Chamber I, ICC-01/04-01/06, 14 March 2012; Concurring Opinion of Judge Christine van den Wyngaert to Prosecutor v. Mathieu Ngudjolo Chui, Jugement rendu en application de l'article 74 du Statut, Trial Chamber II, ICC-01/04-02/12, 18 December 2012.

26 Statute of the CAE available at: www.chambresafricaines.org/pdf/Accord\%20UA-Senegal \%20Chambres\%20africaines\%20extra\%20Aout\%202012.pdf.

27 Ibid.

28 Ordonnance de Non-Lieu Partiel, de Mise en Accusation et de renvoi devant la Chambre Africaine Extraodinaire d'Assises 13 February 2015. 
Habré had not personally committed violence, ${ }^{29}$ but rather found his culpability to reside in his active participation and awareness as the head of a state apparatus that committed those crimes. In this way, the investigating judges found Habré guilty both for the common plan (JCE) hatched by his government and for his responsibility as commander, at the top of the leadership pyramid.

The 30 May 2016 judgment, however, significantly changed the legal rationale under which Habré was convicted. The judgment found Habré both indirectly and directly culpable for violations of IHL. For each of the crimes charged by the Ordonnance (crimes against humanity; war crimes; torture) the judgment found Habré not only individually responsible in his capacity as co-conspirator in a common plan (JCE) and hierarchical superior (command responsibility), but also directly responsible. Moreover, the judgment also further found Habré directly and indirectly responsible for rape and other forms of sexual violence. This aspect of the case was virtually unexplored in the Ordonnance ${ }^{30}$ and emerged through the 19 and 20 October 2015 testimony of Khadija Hassan Zidane and Defala Kaltouma. ${ }^{31}$ Following these witnesses' testimonies, the Human Rights Center at the University of California, Berkeley filed an amicus curiae brief urging the Trial Chamber to include rape and sexual violence in the crimes with which Habré was charged. ${ }^{32}$

The 30 May 2016 judgment, which found Habré guilty of crimes against humanity, war crimes and torture, thus found him to have both directly and indirectly committed each of these crimes. Yet, while there is little doubt that Habré closely and personally oversaw a repressive state apparatus that committed extensive violations of IHL, the evidence of Habrés direct commission of crimes is much less well-developed.

29 "Non pas parce qu'il aurait personnellement pris part à la commission des faits, mais plutôt parce qu'il en aurait été le cerveau, l'organisateur en chef." Ordonnance de Renvoi p 166. The Ordonnance, in citing instances where Habré had personally intervened, names instances where Habré had given orders to torture. The only exception is the testimony of Djibrine El Djonto, one of the defendants named in the indictment, tried and sentenced in Chad in 2015, and not made available to CAE investigators during the four Rogatoires made to Chad leading up to the trial. The Ordonnance cites the 1990 Truth Commission report wherein Djibrine El Djonto represents himself as a victim of Habré, who had reportedly interrogated Djibrine El Djonto and slapped his cheek hard enough to leave a mark. Ordonnance, p. 170, footnote 528.

30 Sexual abuse as an element of torture applied by Habré and his associates was mentioned only in passing, on p. 136 of the Ordonnance and in testimony from a witness regarding rape in jail, p. 165.

31 Summaries of these testimonies are available at: http://trustafrica.org/images/ICJ_reports/EAC\%20Trial\%20Hearing\%20Report\%20-\%2019th\%20September\%202015\%20-\%20English.pdf, http://trustafrica.org/images/ICJ_reports/EAC-\%20Trial\%20Hearing\%20Report\%20-\%2020th \%20October\%202015\%20-\%20English.pdf (last accessed 20 January 2017).

32 'Rape and Other Forms of Sexual Violence as Crimes Against Humanity, War Crimes and Torture Under Customary International Law', available at: https://www.law.berkeley.edu/wp-content/ uploads/2015/04/MICUS-CURIAE-BRIEF-OF-THE-HUMAN-RIGHTS-CENTER-AT-THEUNIVERSITY-OF-CALIFORNIA-BERKELEY-SCHOOL-OF-LAW-AND-INTERNATIONALEXPERTS-ON-SEXUAL-VIOLENCE-UNDER-INTERNATIONAL-CRIMINAL-LAW-Eng.pdf (last accessed 10 January 2017). 
Consider the example of the rape of Khadija Hassan Zidane, the only finding made by the Trial Chamber to be overturned by the Appeals Chamber. During trial, Zidane testified that Habré himself had raped her, a charge that emerged for the first time during her testimony on the stand. The judgment found the witness Zidane 'credible', noted that in ICL corroboration of sexual violence is not necessary ${ }^{33}$ and further noted that a following witness corroborated Zidane's testimony in testifying that Zidane had spoken of Habré raping her at the presidential palace.

Habré's court-appointed attorneys maintained that Zidane's rape testimony emerged only because the president of the Trial Chamber 'goaded' her into this allegation. ${ }^{34}$ Testimony regarding sexual violence is, of course, sensitive and difficult to elicit from witnesses, and the problem of witnesses' 'changing stories' and the challenge to the rights of the defence this presents clashes directly with longestablished difficulties associated with enabling assaulted witnesses to come forward. As noted above, the final appeals judgment overturned the Trial Chamber's finding of guilt regarding the rape of Khadija Hassan Zidane. Yet, except for this one act, the Appeals Chamber let stand the Trial Chamber's findings of guilt regarding Habré's direct commission of crimes and left the Trial Chamber's legal analysis of Habré's culpability intact.

Although evidence for Habré's direct commission is considerably less well corroborated than that of his indirect commission, the CAE trial court used both in its finding of Habré's guilt. Why would the Trial Chamber rely on uncertain, legally unnecessary evidence to establish guilt? One possibility is that the factual uncertainties of Habré's direct commission were added to help shore up the legal uncertainties of the ICL doctrine under which the crimes he orchestrated through his repressive state apparatus occurred. As discussed above, JCE is a novel theory of liability arising out of common law conspiracy and was developed and employed at the ICTY as a type of 'magic weapon' for the prosecution (Ambos 2007). It has been formally rejected by the ICC in favour of other modes of collective commission and is in retreat even at the ICTY where it was first articulated . For a civil law, Senegalese audience, JCE as a theory of liability may stretch credulity, requiring more concrete forms of culpability (such as Habrés direct commission) for a finding of guilt to pass the conviction intime (the requisite standard of guilt) of the trial judge.

In the Trial Chamber's mixture of direct and indirect commission in response to the uncertainties of international legal doctrine, we see a local challenge to ICL doctrine. Where the Investigating Chamber accepted ICL and applied it as received, the Trial Chamber reconfigured facts and standards in order to reach a conviction. This suggests a novel pathway and expansion of ICL doctrine made by the CAE.

33 See 30 May 2016 Prononce et Resume de Jugment dans l'Affaire Le Parquet General contre Hissein Habre (summary provided by Human Rights Watch, see footnote 2).

34 See summary of arguments before Appellate Chamber, 9 January 2017, Maitre Ballal, available at: https://competence-universelle.org/tag/khadidja-hassan-zidane/(last accessed 16 January 2017). 


\section{Establishing Legitimacy at the CAE}

This final section considers the Habré judgment through the lens of legitimacy. As noted in the introduction, the CAE faced a structural hurdle from its origin, in that it was always politically an ad hominem court set up to try (and arguably to convict) one person, Hissène Habré. No amount of fudging or semantics can obfuscate this. ${ }^{35}$ The questions that followed thus concerned a series of potential traps for the institution: could it be successful if it successfully tried the man it was constructed to try? Could it possibly be successful if it didn't try him? How should guilt and acquittal be understood in these circumstances? And how should we understand the answers to these questions in terms of 'legitimacy'?

\subsection{Legitimacy for International Courts}

Bodansky (2012) defines legitimacy as "the justification and acceptance of political authority.... A legitimate institution or leader has a right to exercise authority - it has a right to rule ... - while an illegitimate one does not". International institutions all struggle with achieving legitimacy, and this is particularly true for international courts (Koskiennimmi 2002; von Bogdandy \& Venzke 2014). Jan Klabbers has written extensively on the particular problems international courts face as institutions. Klabbers (2015) argues that the partner/agent relationship between international organizations and their funders can lead to conflicts of interest when the goals of third-party beneficiaries do not align with funders' interests or priorities. Klabbers defines these accountability problems as pervasive in international organizations generally and highlights that they are particularly problematic for international courts. These structural accountability deficits are particularly problematic for international courts, Klabbers notes, because legitimacy before third parties is central to judicial capacity.

In this sense, we can understand a central legitimacy challenge faced by the CAE lying in the navigation of funder interests and third-party beneficiaries. Since the CAE's largest funder (Chad) was also arguably its most central thirdparty beneficiary (given that Déby has sought to put Habré on trial since deposing him in 1990), one of the central challenges faced by international courts is mitigated for the CAE.

Of course, the threat on the other side becomes that which the Nuremberg Tribunal, discussed in the first section, faced, a form of 'victor's justice'. A CAE carrying out Déby's political will would not qualify as a 'legitimate' court. Also, given contemporary 'backlash' in Africa against the ICC and other international courts (Alter, Helfer \& Madsen 2018; Brett \& Gissel 2019), it was important that the CAE be an 'African' court. Thus the form, doctrines, practices, personnel and way of working all proved critical in shoring up the CAE's legitimacy, particularly

35 For example, Art. 3 of the Statute of the CAE states that the court is set up to "prosecute and try the person(s) most responsible for crimes and serious violations of international law, customary international law and international conventions ratified by Chad, committed on the territory of Chad during the period from 7 June 1982 to 1 December 1990". Furthermore, five additional individuals were named in the indictment; none of them were made available to the CAE by Chad or other countries, and thus they did not stand trial with Habré. 
given the somewhat foregone conclusion of Habré's culpability (because was there any significant chance, once the $\mathrm{CAE}$ was up and running, that Habré would not be convicted?) The CAE was almost entirely staffed by Senegalese judicial personnel who worked smoothly and well; even Habré's personal attorneys granted that the CAE's staff were quite professional. ${ }^{36}$ This is a significant admission given that Habré's chosen attorneys rejected the legitimacy of the CAE as an institution and represented their client by refusing to appear before the CAE, instead 'pleading from the hallways' of the institution in fiery interviews granted to media.

From the CAE's ordonnance, judgment and appeal, we can see that the CAE's use and application of ICL doctrine, particularly the Trial Chamber's finding of direct and indirect (through JCE) commission, served as a method of legitimacy building. In shoring up a contested and imprecise international doctrinal standard (JCE) with more accepted normative applications of criminal accountability (direct commission), the CAE suggested a doctrinal method for increasing its legitimacy, which also voiced its independence and singularity. In this way, the CAE offers a model for other hybrid institutions moving forward.

\section{Bibliography}

Aksenova, M., Complicity in International Criminal Law, Hart 2016.

Alter, K.J., Helfer, L.R. \& Madsen, M.R. (Eds.), The Authority of International Courts, Oxford, Oxford University Press, 2018.

Ambos, K. 'Joint Criminal Enterprise and Command Responsibility', Journal of International Criminal Justice, Vol. 5, No. 1, 1 March 2007, pp. 159-183.

Arendt, H., Eichmann in Jerusalem: A Report on the Banality of Evil, New York, Penguin Books, [1963] 2006.

Bodansky, D. 'Legitimacy in International Law and International Relations', in J. Dunoff \& M. Pollack (Eds.), Interdisciplinary Perspectives on International Law and International Relations: The State of the Art. Cambridge, Cambridge University Press, 2011, pp. 321-342.

Bogdandy, A. von, \& I. Venzke, In Whose Name? A Public Law Theory of International Adjudication, Oxford, Oxford University Press, 2014.

Brett P. \& Gissel L.E., Africa and the Backlast Against International Courts, Zed Books 2019 (forthcoming).

Carlson, K.B. 'International Criminal Law and Its Paradoxes: Implications for Institutions and Practice', Journal of Law and Courts, Vol. 5, No. 1, 2017, pp. 33-53.

Carlson, K.B. Model(ing) Justice: Perfecting the Promise of International Criminal Law, Cambridge, Cambridge University Press, 2018 (forthcoming). 
Danner, A.M. \& J.S. Martinez., 'Guilty Associations: Joint Criminal Enterprise, Command Responsibility, and the Development of International Criminal Law', California Law Review, Vol. 93, No. 1, 2005, pp. 75-170.

Drumbl, M.A. Atrocity, Punishment and International Law. , Cambridge: , Cambridge University Press, 2007.

Fletcher, G.P. 'Collective Guilt and Collective Punishment', Theoretical Inquiries in Law, Vol. 5, No. 1, 2004, pp. 163- 178.

Grenawalt, A. 'Pluralism in International Criminal Law', Leiden Journal of International Law, Vol. 25, No. 4, 2012, pp. 847-855.

Jain, N. Perpetrators and Accessories in International Criminal Law: Individual Modes of Responsibility for Collective Crimes, Oxford, Hart Publishing, 2014.

Klabbers, J. An Introduction to International Institutional Law (Third Edition), Cambridge, Cambridge University Press, 2015.

Koskenniemi, M. 'Between Impunity and Show Trials', Max Planck Yearbook of United Nations Law, Vol. 6, 2002, pp. 1-35.

Koskenniemi, M. Fragmentation of International Law: Difficulties Arising From Diversification and Expansion of International Law. Report of the Study Group of the International Law Commission, Helsinki, Erik Castrén Institute of International Law, 2007.

May, C. The Rule of Law: The Common Sense of Global Politics, Cheltenham, Edward Elgar, 2014.

Ohlin, J.D. 'Joint Criminal Confusion' New Criminal Law Review Vol 12, 2009, pp. 406-19.

Ohlin, J.D., E. van Sliedregt \& T. Weigend, 'Assessing the Control Theory', Leiden Journal of International Law, Vol. 26, 2013, pp. 725-746.

Osiel, M.J. 'Modes of Participation in Mass Atrocity,' Cornell International Law Journal, Vol. 38, No. 3 , Article 7, 2005, pp. 793-822.

Teubner, G., 'Exogenous self-binding: How national and international courts contribute to transnational constitutionalization' in G. Corsi, E. Esposito and A. Febbrajo (eds.). Transconstitutionalism. Ashgate, Farnham, 2015.

Schabas, W., Unimaginable Atrocities: Justice, Politics, and Rights at the War Crimes Tribunals, Oxford, Oxford University Press, 2012.

Sliedregt, E. van, 'Command Responsibility at the ICTY - Three Generations of Case-law and still Ambiguity', in B. Swart, A. Zahar, and G. Sluiter (Eds.), The Legacy of the International Criminal Tribunal for the Former Yugoslavia. Oxford, Oxford University Press, 2011. 